\title{
Ordinary Themes Presented with an Extra-ordinary Talent: An Overview of Emily Dickinson's Notable Poems
}

Yousef. A.N. Aldalabeeh*

Language Center, Al-albayt University, Mafraq, Jordan

Corresponding Author: Yousef. A.N. Aldalabeeh, E-mail : aldalabeehyousef yahoo.com

\section{ARTICLE INFO}

Article history

Received: November 19, 2017

Accepted: January 21, 2018

Published: May 01, 2018

Volume: 7 Issue: 3

Advance access: March 2018

Conflicts of interest: None

Funding: None

\begin{abstract}
As a poet with varied writing styles and extra-ordinary talent, Emily Dickinson occupied a very prestigious position in the field of American literature. Her poetry deals with a unique and large number of thematic expressions. This paper aims at introducing the unfolded, underlying and amazing thematic expressions of Emily Dickinson's notable poetry. To unveil these themes of death, love, nature, immortality, pain and suffering from her widely recognized poetry, secondary source of data has been used. In this study, an effort also has been made to trace, examine, and explore the various themes with outstanding style of presentation of her poetry and their impact on readers and critics. Many researchers and critics have spent their great exertion to trace out these themes and they became successful in this regard. It is hoped that this study will also be a part in this line of contribution and serve the purpose for which it is designed.
\end{abstract}

Key words: Outstanding, Death, Love, Nature, Immortality, Pain and Suffering

\section{INTRODUCTION}

Emily Dickinson is regarded as a praise-worthy American figure who has already earned a place in American Literature in the early twentieth century. In one respect, she stands in sharp contrast to her great contemporaries like Whitman, Emerson, Hawthorne, and Thoreau. Her interests were wide and varied which encompass transcendental, meditative, romantic, metaphysical and mystical themes. Large number of her works was written on subjects of popular and universal solicitude. The concreteness of Dickinson's images and visions has been drawn from her own observation and experience which impressed the scholars and critics.

Although Dickinson was influenced by Bible, Shakespeare, Emerson and other sources, she has come to be known as being one of American's major poets in the twentieth century. In the present time the poet continues to fascinate and captivate readers. Despite the fact that she withdrew early from social life and lived at home throughout her life in Amherst, Massachusetts, she displays a range of feelings and perceptions that few poets can match. Although she was destined to become a semi-private poet, she seems to have experienced a surfeit of mystical presence that menaced at different times in her life to overwhelm her. "Far from the little figure of frustrations and renunciations and regrets, we will come to see her as a poet of great strength, courage, and singleness of purpose." (Sewall, 1963, P. 8). As a result, her thinking was suffused with abnormally heightened spiritual and mental awareness which she struggled to contain within the limits of her creative outpouring. The result was both positive and negative. The result may be negative because she is more incomprehensible than comprehensible. Except a few number of her poems being susceptible to easy interpretation while an ambiguity falls over the rest.

\section{Notable Themes of Her Poems}

As her poems reveal, her significant life was passed in the interior of her love. The life and personality of Emily Dickinson speak clearly through her poems. "She preferred the world of her own creation to the objective world of observable fact"(Thachrey, 1963, p. 67). She belonged to no school but in a way, she belonged to almost every school of poet. Even her critics noted that she herself has put almost insurmountable obstacle, her poetry distinguishes as one thing only to reveal itself as another. Her critics are of unanimous that even a close reading is not necessarily rewarding. "Her poetry is a magnificent personal confession, blasphemous and, in its self-revelation, its honesty, almost obscene. It comes out of an intellectual life toward which it feels no moral responsibility" (Tate, 1959, p. 213).

While other members of her family were busy fighting pretty but petty battles, Dickinson was incorrigibly involved with serious discussions about life and death. "Death, and the problem of life after death, obsessed her. She seems to have thought of it constantly"(Aiken, 1968, p. 162). Very early in her life, she started adopting social and intellectual postures which caused embarrassment not only to her but also to those who were in contact with her. She once wrote to Higginson 
(1914) that "they talk of hallowed things, aloud - and embarrass my Dog. He and I don't object them, if they'll exist their side" (271). The problem with Dickinson, as with Robert Frost, is that she thought of questions which had no answers. This was the reason for the embarrassment.In a poem "We introduce ourselfes" She writes:

We introduce ourselves

To Planets and to Flowers

But with ourselves

Have etiquettes

Embarrassments

And awes (L 1 - 6)

This seeking for answers where there were none was also the reason for many paradoxes found in Dickinson' poetry, especially the one related to man's increasing knowledge of the world outside and the decreasing knowledge about one's inner self. The latter also led to Dickinson's better understanding of nature and alienation from the self and surprisingly, therefore, to a correlation between the outer world and the inner.

Undoubtedly, Emily Dickinson is a popular lyric poet and she is "perhaps next to Walt Whitman the greatest American poet of the last century" (Ward, 1932, p.43)). The themes, thought and philosophy in a poem are as important and valuable as are the art and craft of it. In this connection, Brook and Warren rightly remark that, "The theme (of a poem) embodies the attitude toward life that grows out of the little drama - the evaluation of human experience" (1960, p. 34).

One could identify four major themes in Dickinson's poetry- death, nature, love, and relationship to God. She tackles death in many ways. Sometimes she personified it, and sometimes she afraid of it, and sometimes she faced it with challenge. In a large number of her poems e.g. "Because I could not stop for Death" (No.712), "There has been a Death in the Opposite House" (No 389) and in the poem "Tie the string of my life, My Lord" No. 279), Dickinson associates death with a horse driven carriage which symbolizes death. In poem No. 279 a coachman rides the carriage and the poet also inspects the horses. The carriage will carry her precious life to the divine world. She judges the power of the horses, their swiftness and feels confident that the horses are ready to eternal galloping: "Rapia! That will do!" Towards the end of journey, she would say goodbye to the earthly life she had led: "Goodbye to the life I used to live". In poem "I died for beauty, but was scarce" No. 449, a worshiper of beauty dies for the interest of the same but his spirit faces problems of being accommodated in the grave as the adjoining space is occupied by a person who passed away for truth:

I DIED for beauty, but was scarce

Adjusted in the tomb

When one who died for truth was lain

In an adjoining room-(L 1 - 4)

Both begin a discussion and they question each other to realize the reason of their death. Both agree that truth and beauty represent the same opinion, ideology and concept, and find that they are synonyms of each other:

He questioned softy why I failed?

For beauty," I replied,

"And I for truth, - the two are one:

We brethren are", he said.(L 5-8)
They meet each other as if lost friends rejoin each other to celebrate their meeting like royal receiving. They keep on visiting each other's grave until their bodies crumbles:

And so, as Kinsman met a night,

We walked between the rooms,

Until the moss had reached our lips,

And covered up our names.(L 9-10)

The message that truth and honesty are one and the same has already been conveyed to us by Keats in his poem "Ode on Grecian Urn".

Beauty is truth, truth beauty, - that is all

Ye know on earth, and all ye need to know..(L $49-50$ )

Dickinson's death poems generally develop in a grim, dull, morbid and serious atmosphere but in the poem No. 54, death is accompanied with a sportive and lifelike atmosphere. Death in other words seems to be a loss but in this poem, that doesn't mean a loss at all.

In some of her poems nature is a source of pain, suffering and death "nature may thus be a symbol of death, representing much the same idea as the corpse in the poem beginning " "Twas warm at first, like us," but involving a more complex range of association." (Winter, 1947, p. 292). Happiness in the living life becomes a part and parcel of the soul after death. The poem, "If I Should Die", suggests that prosperity and riches become a source of restlessness to soul posthumous-ly. This is the ideology which the poet conveys to us through the poem:

If I should die,

And you should live,

And time should gurgle on,

And morn should beam,

And noon should burn,

As it has usual done;

If Birds should build as early,

And Bees as bustling go, -

One might depart at option

From enterprise below!

' $\mathrm{T}$ ' is sweet to know that stocks will stand

When we with Daisies lie,

That Commerce will continue,

And Trades as briskly fly.

It makes the parting tranquil

And keeps the soul serene,

That gentlemen so sprightly

Conduct the pleasing scene! (L 1 - 18)

People take birth, grow up, pass through old age and die. Does their death create a gap or void which will never be occupied by someone from among the living ones? The answer to this question is probably 'No' according to the poet. Austin Warren writes, "Emily's most characteristic difficulties are with the morals of the Bible., she neither rejects nor accepts It [the Bible] without question and reservation." (Warren, 1957, p. 573). One generation becomes out dated and passes away and its place is taken by a new generation. Death of an individual or death of a generation can never cause such a loss which cannot be compensated. Whether it is nature, culture, trade, commerce or industry, all are unaffected by Death. 
In some other death poems, Dickinson accepted death over a scope of time. The hour at which death impends is quite uncertain. Since it is beyond of our wish to command death, it is involuntary. But in this poem, she accepts death as voluntary, saying: "One might depart at option" (L 9) which means that we can control death. But in the poem "GOING to heaven!" (79), Dickinson expresses her uncertainty about death. No oracle priest, fortune-teller or horoscope can an-swer the question when death will raid life. Such a ques-tion surprises us, but death is sure, certain and unavoidable. Time stretches before us in the constant panorama of more and more days, months and years, and we remain listless of death. Watching someone else die reminds us of the fact that one day we too must die, but we usually picture that day is far away in the womb of future. When we are in good health, death is unimaginable, and we rarely think about it but still death is unavoidable:

GOING to heaven!

I don't know when,

Pray do not ask me how,-

Indeed, I 'm too astonished

To think of answering you!

Going to heaven!-

How dim it sounds!

And yet it will be done

As sure as flocks go home at night

Unto the shepherd's arm! (L 1 - 10)

Further the poem enlightens us with a view that Heaven is our permanent abode and that Earth is a place where we are visitors for a short duration, tourist like. When our time for one life is over, we proceed to our permanent abode Heaven.

Perhaps you're going too!

Who knows?

If you should get there first,

Save just a little space for me

Close to the two I lost!

The smallest "Robe" will fit me,

And just bit of "Crown"-

For you know we don't mind our dress

When we are going home. (L 11 - 19)

And yet death remains a mystery, an unending source of anxiety but she overcomes the tension created by universalizing her dilemma about death, identifying it with the process of creation.

Death though her concern was, Dickinson did not disre-gard life or the idea of it. "To her, life was rich and all aglow with God and Immortality"(Kilcup, 1997, p. 225).In the poem "Do People Moulder Equally", she is also involved with the metaphysics of death, the death of death:

I need no further argue-

That statement of the Lord

Is not controvertible-

He told me, Death was dead (L 13 - 16)

Poem "Because I Could Not Stop for Death" is Dickinson's superior poems on death in English poetry. She presents the idea and the vision of death where one can pass from the short life on the earth to immortality life in the heaven. Reeve remarks "This is one of the best of those poems in which Emily triumphs over death by accepting calmly, civilly, as befits a gentlewoman receiving the attentions of a gentleman. It is an essay in death-in-life. (Reeve, 1976, p.20)

However, her descriptions of death are real. In some of her death poems like "There's been a Death, in the Opposite House" and "I heard a Fly buzz - when I died" she deftly portrays the attitude and responses of those around and of the dead person as well. "The transaction is homely and easy, for the poet has complete sophistication in these matters, having attended upon deathbeds, and knowing that the terror of the events is mostly for the Observers". (Ransom, 1963, p. 90). Her curiosity about experience of a person at the time of death is a part of her exploration to unravel the mystery of death.

Besides being concerned with the death and its manifestations, Dickinson composed numerable love poems. Though she remained unmarried throughout of her lifetime, yet most of her successful love poems center round the rituals of marriage. She has a choice for a divine and earthy lover, but she often prefers the divine one. In the poems such as "Of all the Souls that stand create" (p. 664) and the poem "The Soul selects her own Society" (p. 303), she chooses the divine lover rejecting the earthy one, but this doesn't mean that she is strictly against an earthly lover, the beloved also becomes divine.

In Emily Dickinson's philosophy of love, we can trace the impact of her paradoxical views in religion and spirituality. She was both a Christian and a Pagan side by side. She had full faith in Christian values of life, but she showed little faith in dogma, blind faith and false traditions. In this context, her biographer Thomas H. Johnson (1972, p. 4) remarks "she rebelled against the orthodoxies into which she had born, yet in her defiance she was rooted with the passionate attachment to the world - in - small wherein she enacted her daily round of duties". The typical attitude of faith and doubt, hope and despair became a part of formulating a paradoxical philosophy of love. St. Armand (1984) has tried to relate her poetry to the American Victorian culture. He calls her a spiritual orphan and says, "All her life, Emily Dickinson sought spiritual brothers and sisters". (p. 127)

It is very likely that she could not get satisfactory answers to her searching question, and thus, her "only playmate was poetry" and this poetry proceeded experimentally to sing of love and nature and tried to formulate a philosophy of love.

Unlike the blind faith, her poetic faith is complementary of her philosophy of love. In this way, she anticipates Mathew Arnold, her British contemporary, who said "there is not a creed which is not shaken, not an accredited dogma which is not shown to be questionable, not a received tradition which does not threaten to dissolve.... Poetry attaches its emotion to the idea; the idea is the fact. The strongest part of our religion today is its unconscious poetry"(Arnold, 1965, p. 109).

Her love poems are full of illuminating love passions and she often sings about love-dreams, flowers, love letters, surrounding of the lover and the beloved, bridal gown etc. Her love lyrics have been enriched with eroticism, sexual passions, sensuous enjoyment, passionate experience, as in poem No. 493. 
The world - stand-solemner- to me-

Since I was wed - to Him-

A modesty befits the soul

That bears another's - name-

A doubt- if it be fair - indeed-

To wear that perfect - pearl-

The man - upon the woman - binds-

To clasp her soul - for - all

A prayer, that it more angel-prove-

A whiter Gift-within -

To that munificence, that chose-

So unadorned-a Queen-

A Gratitude - that such be true-

It had esteemed the Dream-

Too beautiful - for Shape to prove-

Or posture - to redeem! (L 1 - 16)

In her love lyrics, Dickinson has used conventional matrimonial terminology related to the Roman Catholic Church. She talks about the wedding ring, beautiful diamond fitted to the wedding ring, white marriage gown. The treatment that she meets out to the poems embodying the theme of love reminds us of the marriage in Roman Catholic tradition.

Like Arnold, Emily Dickinson doesn't favor dogma or superstations, but she prefers the poetic religion which teaches and tells us about basic values of love and life, as she says: "the bible is an antique volume - written by Faded Man”. (P.1545)

Some of her poems faded away because of obscurity as she alludes to the image of an unknown lover. The identity of the unknown lover was only known to her alone and to no one else as it is a biographical detail which she never revealed. According to her critics and annotators, the personal references in her love lyrics may be to Charles Wadsworth who was a preacher in Philadelphia.

For Emily Dickinson, soul and love go together. Love's fulfillment lies in the body but temporarily, its entire satiety depends on soul in various shapes and shades. For instance, in poem 303, the poet perceived soul as a divided queen which is merged and mingled in her own selected society:

The Soul selects her own Society -

Then - shuts the Door -

To her divine Majority -

Present no more -

Unmoved — she notes the Chariots - pausing -

At her low Gate -

Unmoved - an Emperor be kneeling

Upon her Mat -

I've known her - from an ample nation -

Choose One -

Then - close the Valves of her attention -

Like Stone - (L 1 - 12)

Dickinson lived in a world of love, stars, flowers, bright sunshine all of which helped to develop her sensuous settings. In some of her love poems she employs the word "filament" which reveals a symbolic connotation. According to one implication, it means coiled piece of wire emitting light rays to unveil her love laden life, and according to another implication it means a flower with the filament which is cen- tral to the flower and holds pollen grains that biologically reproduces more flowers.

The moment spent on the lap of love on the company of God is "the soul's superior instants," when the poet realizes the "colossal substance, of immortality. The poet says:

THE SOUL'S superior instants

Occur to Her alone,

When friend and earth's occasion

Have infinite withdrawn.

Or she, Herself, ascended

To too remote a height,

For lower recognition

Than Her Omnipotent.

This mortal abolition

Is seldom, but as fair

As Apparition — subject

To autocratic air.

Eternity's disclosure

To favorites, a few,

Of the Colossal substance

Of immortality. (L 1 - 16)

Such moments of infinite love and divine bliss come when the soul emancipates her tethers of mundane love and her mortal ties and indifference and the feeling of detachment are threefold: On the emotional Plame, they are from 'Friend' and all the earthly ties and tethers of physical love.

In the love lyric, she becomes more effective when she fuses physical passions with religious feelings and divinity like Donne did. Such poems induce sensations sustained in spiritual awe. The blending of physical passions with divinity, in her love poems, is quite natural because she found the origin of her love poetry in divine inspiration. Sea imagery is generally associated with the theme of love in Dickinson's poetry. The main objects of her sea imagery are a captivated beloved, an approaching virtuous hero, extensive water etc. Such a setting reminds us of the chivalric and romantic poetry.

The liberated and purified pious is perceived as the heat that shines and scintillates with the light and luster as in the poem No 365 the poet says:

DARE you see a soul at the white heat?

Then crouch within the door.

Red is the fire's common tint;

But when the vivid ore

Has sated flame's condition

Its quivering substance

Without a color but the light

Of unanointed blaze. (L $1-8$ )

Dickinson also examines the idea of love from several angles, giving at once personal and universal dimensions to her expressions: "to caress the bee a severe temptation, but was not temptation the first zest?" (L. 301). She refers to the plight of an unmarried woman's failure love as an "eccentric Bereavement". In spite of such afflicting experiences, she cannot refrain from "surprise and love," because "Love is its own rescue, for we - at our supremist, are but it's trembling Emblems". (L 522) 
Love, like nature, becomes a mystery to Dickinson. She feels that love's "Wisdom" is so large and it's "Truth" so "manifold" that it is beyond comprehension.

Emily Dickinson's treatment of the vision and philosophy of love shows her wide range of perfection, observation and experience. She regards love as a spiritual power, a catalyst and an emotional force. The deep sorrow and the loss of the lover is the theme of many other poems. She displays the vision of love in many shapes and shades. She also displays in her singular artistic and paradoxical manner. She also finds out the contradictory aspects of love in the form of spiritual and physical, divine profane blissful and baneful, genuine and false, sentimental and emotional, and ecstatic and painful.

Though Dickinson has written on "Wild Nights" and "Eden" themes, she limits herself to the emotional tangle that love implies; and in the process, brings out the tension and the drama that such a theme demands. She doesn't describe an event of love; she portrays the situation, as it were in the metaphors which speaks for themselves.

Many poems, dealing with the theme of pain and suffering, have been treated by Dickinson in a varied manner. The feeling of pain and suffering comes out of horror. Tension is the other root cause which sprouts the feeling of pain and suffering. The poems embodying this theme deal with misery, anguish, despair and disappointment. Dickinson is predominately examining the nature and the cause of suffering and pain. The range of pain and suffering in her poetry is wide. She talks about various types of pain such as "lesser pain", "greater pain", "true pain" and "larger pain".

She separates the 'lesser pain' that will heal, from the 'greater pain' that will not; and she chooses the latter category as her special concern. She says that 'true pain' is necessary for one's existence and its departure causes depression. Then she talks about 'larger pain' which provides enlightenment and it originates from personal experience of grief.

She perceives pain causing a positive as well as a negative impact on human life. The impact of pain and suffering, according to her, greatly strengths man; and enables him to bear increased stress. Pain elevates man to a new height and helps him to develop an aristocratic behavior with other who experience anguish. Her belief in the abiding nature of pain reflects a basic Calvinistic doctrine.

She often tries to link pain with death, soul and pleasure. Pain and suffering causes a shock which leads to death. It provides proper atmosphere to the sensation of a dying man and thus facilitates death. The impact of death is chilling, freezing and benumbing as we notice in the poem "After Great Pain a Formal Feeling Comes" (No.341) which is nothing but death of sensations. Extreme pain eases the final departure of the soul from the body. The knowledge of pain and suffering is the yardstick to measure the depth of a human soul. Such ideology is reflected in her poem: "I measure every grief I meet" (No.561). She adds that the disappearance of pain from one's body renders the soul lonely.

She evolves the pleasure and pain antithesis in many of her poems. To know the real taste of pleasure one should have experiences of pain and suffering. "I had been hunger all the years" (p. 439), this poem is the finest of her poems which deals with the suffering of thirsty and hunger. Likewise, joy is taught by suffering in the poem "Joy to have merited the Pain" (p. 788). She takes full advantage of the contrastive method to make us realize the pleasure and pain antithesis when she writes the following lines in the poem No. 572

"Delight— becomes pictorial—When

viewed through pain"- (L 1 - 2)

Poem No. 67 is the champion of pleasure and pain antithesis:

"Success is counted sweetest

By those who never succeed.

To comprehend a nectar

Requires sorest need.

Not one of all the purple Host

Who took the Flag to day

Can tell the definition

So clear of victory.

As he defeated - dying-

One whose forbidden ear

The distant strains of triumph

Brust agonized and clear! (L 1 - 12)

It is through bitterness that one learns how to appreciate the enjoyment. The defeated and dying solider appreciates the meaning of victory more than the victorious themselves. Her poems which embody the theme of pain and suffering have been composed in a style to an approximate style of typical romantic ballad, high beating waves, ship wrecked sailors etc.

There are number of reasons which could be cited for the existence of the theme of suffering and pain in her poetry. Her personal experience may be one of the main reasons. Her secluded life within closed quarters where she suffered isolation may be one of the reasons for such themes of pain and suffering. Her own ill health and melancholy may also be a contributing reason. In addition to that privations were the main reason of her despondency. Wilbur remarks "for her there were three major privations: she was deprived of an orthodox and steady religious faith; she was deprived of love; she was deprived of literary recognition." (Wilbur, 1996, p. 54)

Dickinson relates the themes of pain and suffering with the death, but it is not always so. She links the themes of pain and suffering with love also. In the following lines of poem No. 673, she finds love distilling uncertain pain:

The Love a Life can show Below

Is but a filament, I know,

Of that diviner thing

That faints upon the face of Noon -

And smites the Tinder in the Sun -

And hinders Gabriel's Wing -

'Tis this - in Music - hints and sways -

And far abroad on Summer days -

Distils uncertain pain - (L 1 - 9)

In poem NO. 1729, she receives an arrow from the hand whom she loved. Obviously, it is a painful and disappointing experience because of failure of love: 
I'VE got an arrow here;

Love the hand that sent it,

I the dart reverem $(\mathrm{L} 1-3)$

According to her views, if we love someone, the greatest sacrifice that we can give is our soul or we die for him. Dickinson reflects same views in poem No. 573.

The Test of Love - is Death -

Our Lord - "so loved" - so saith -

What Largest Lover - hath -

Another - doth - (L 1 - 4)

Besides poems on death and love, Dickinson composed fantastic nature poems. Anderson says that "for her it was an endless carnival of entertainment. It was a source of metaphor to illustrate the truths of her interior world, the one she created and the only one she could understand" (1960, p. 162). Her nature poems reflect nature in different forms and aspects. She includes flies, butterflies, insects, birds and violent powers of nature such as winds, rain, thunderstorms, lightening, drought and earthquakes. The most notable elements of nature as the noon, the sun, the sea, the sky, the clouds, the rivers, the mountains and all fascinated her. The natural phenomenon like seasons, mornings, evening, dawn, dusk, sunrise, sunset, aurora, eclipse get prominence in her nature poems and they reflect an appropriate change that happens in nature.

Dickinson's attitude toward nature is not stationary but dynamic. She takes different attitudes towards nature. Chase is of the view that for Emily Dickinson "Nature is aggressively a fact so consequential and inclusive a fact that it symbolizes itself" (Chase, 1965, p. 166). Nature remains a mystery for her. She has her own vision of nature. In some of her poems, she described nature as a source of pleasure and joy, but in another poems nature is described as an aggressive one. According to her, to understand nature, one will have to desert the fullness of human life and say good bye to human life. She wrote poems wherein human life has been discovered from nature. In the following poem No 647, division is made between man and nature.

A LITTLE road not made of man,

Enabled of the eye,

Accessible to the thrill of bee,

Or cart of butterfly.

If town it have, beyond itself,

' $\mathrm{T}$ is that I cannot say;

I only sigh, - no vehicle

Bears me along that way. (L $1-8$ )

The other poems which dichotomy between human life and nature are "Twas warm - at Firs_ LikeUs_" (No. 519) and "Further in Summer than the Birds" (No. 1068) and "A Bird came down the Walk" (No. 328).

Like Whitman who found divinity in nature, she too held the opinion that nature somehow participated in the mystery of divinity. But she did not believe that nature can plan or order to do anything. She rarely expressed the inherent pantheism found in transcendental over soul, and only in a poem like "All circumstances are the Frame", where God has been tentatively identified with nature. Gelpi says that nature for Emily Dickinson "was the material medium through which God on the life spirit touched man on through which man touched him on it”. (Gelpi, 1971, p. 74)
In some of her writing, her attitude toward nature becomes Wordsworthian. For Wordsworth, nature was mother, teacher, guide and nurse. Wordsworth accepted nature as a living influential character. Often nature terrorized, confronted and pleased him. Like Wordsworth, in many of her conventional poems Dickinson praised nature as "Nature The Gentlest Mother" (p. 790) who soothed and comforted her children. She expresses a sentimental enthusiasm about the red breast of the robin and butterfly's beautiful color. But her soothing attitude to nature doesn't remain consistent throughout. In her later nature poems she takes an opposing attitude to nature. She focuses on the losses and harms which nature can cause to the human beings. Rather than providing comfort to human beings, nature mocks at them. Dickinson is one of the poets who used her own experience in her poetry and this is clear when she uses many times the word "I" in some of her poems, as Macleish mentioned "she is already in the poem before she begins it"(MacLeish, 1963, p. 160). She looks at death sitting at the core of nature in form of calamity and destructive power. In the poem "Apparently with no surprise" (No. 1624), she questions if nature had any meaning at all. In the poem No. 364, nature withdraws and becomes indifferent and victimizes those who try to love it.

The Morning after Woe-

'Tis frequently the Way-

Surpasses all that rose before-

For utter Jubilee-

As Nature did not care-

And piled her Blossoms on-

And further to parade a Joy

Her Victim stared upon-

The Birds declaim their Tunes-

Pronouncing every word

Like Hammers - Did they know they fell

Like Litanies of Lead-

On here and there - a creature-

They'd modify the Glee

To fit some Crucifixal Clef-

Some Key of Calvary- (L 1 - 16)

On the theme of nature, Dickinson's moralistic views differ from the other American writers who lived in the ninetieth century such as Emerson and Bryant. For them, the nature poems become didactic and they insist upon divine analogues, but Dickinson neither accepts nature as didactic agency, nor does she use nature as a guide for inducing moralism. Her nature poems include birds, flowers, insect and natural processes which are rarely didactic or don't insist upon divine analogues. "Nature is no longer a friend, but often an inimical presence. Nature is a haunted house, art a house that tries to be haunted." (Dickinson, 1958, p. 236).

\section{CONCLUSION}

Finally, on the basis of the study of her poetry about love, death and nature, it can be said that Emily Dickinson is essentially a poet, not a thinker or philosopher. The different 
themes of love, death, nature and the vision inherent therein are not new themes but she has inculcated and infused a new life and luster into these themes with her singular craftsmanship of poetic genius and her extraordinary power of perception and fine freshness and originality of expression.

Thus we see that in order to shape and formulate her poetic attitude towards nature, love, death, pain and suffering Dickinson borrowed images and concepts from her predecessors and the contemporaries. Commenting upon Dickinson's individuality and the contemporary influences on her, Hartnoll (1994) writes: "Where did Emily Dickinson's poetry come from? She clearly drew influences from Emerson, and the Rhythm ... the essence and her own search for identity"(07). Provoked constantly by the enchanting scenes of nature of New England, and disturbed continuously by the experiences with death, love and God, Dickinson was conditioned to a mode of expression which involved the use of words that evolved themselves into meaningful metaphors and complex concepts. Her authentic portrayal of the disintegrating puritan belief led her to use paradox and irony in the elaboration of her themes. Through the themes she used and the way she expressed them, she has come to gain the important role of a crucial aesthetic link between the seventeenth century metaphysical and the twentieth century neo-metaphysical.

\section{REFERENCES}

Aiken, C. (1958). A reviewer's ABC: Collected criticism of Conrad Aiken from 1916 to the present. New York: Meridian Books.

Anderson, Charles R.(1960). Emily Dickinson's Poetry: Stairway of Surprise. (New York, Holt, Rinehart and Winston).

Arnold. Matthew. (1965). “The Study of Poetry”. Essay on English Literature. ed. F. W. Bateson (London: University of London Press).

Brooks, Cleanth and Warren Robert, Penn. (1960). Understanding Poetry. (New York: Holt, Rinehart and Winston).

Chase, Richard. (1965). Emily Dickinson. New York: Dell Publishing.

Dickinson, Emily. (1963) The Poems of Emily Dickinson. ed. Thomas H Johnson. Cambridge, Mass: The Belknap Press. (All references to poems are from this volume.)

Emily. (1958). Emily Dickinson: Selected Letters. Ed. T. H. Johnson Cambridge: Harvard University.

Gelpi, J. Albert. (1971). Emily Dickinson: The Mind of The Poet. New York: W.W. Norton and Co.
Hartnoll, Emma.(1994). The Works of Emily Dickinson. Hertfordshire, Wordsworth Editions Ltd.

Higginson, David. (1967). Portrait of Emily Dickinson: The Poet and Her Prose. New Brunswick: Rutgers University Press.

Higginson, Mary Thatcher. (1941).The Story of My Life. Boston: Houghton Mifflin.

Johnson, Thomas H.(1972). Emily Dickinson: An Interpretive Biography. (1955; Rpt. New York: Athenaeum).

Kilcup, K.L. (ed.). (1997). Nineteenth-Century American Women Writers: An Anthology. Cambridge, Massachusetts: Blackwell Publishers Inc.

MacLeish, A. (1963). "The Private World: Poems of Emily Dickinson.” Emily Dickinson, A Collection of Critical Essays, ed. Richard B. Sewall. Englewood Cliffs, N. J: Prentice-Hall.

Ransom, Hohn, C. (1963). "Emily Dickinson: A Poet Restored." Emily Dickinson: A Collection of Critical Essays. ed. Richard B. Sewall. Englewood Cliffs: Prentice-Hall

Reeves, James.(1976). Selected Poems of Emily Dickinson. London: Heinemann.

Sewall, R. (ed.).(1963). Emily Dickinson: A Collection of Critical Essays. Englewood Cliffs, N.J.: Prentice-Hall.

St.Armand Barton.(1984). Emily Dickinson and her Culture: The Soul's society. Cambridge, New York: Cambridge University Press.

Tate, A. (1959). Emily Dickinson. Collected Essays. Denver: The Swallow Press.

Thackrey, Donald E. (1963) "The Communication of the Word." Emily Dickinson: A Collection of Critical Essays. Ed. Richard B. Sewall. Englewood Cliffs: Prentice-Hall.

Ward, A.C. (1932). American Literature: 1880-1930. London: Methuen.

Ward, Theodora. (1868).The Capsule of the Mind: Chapters in the life of Emily Dickinson. (Cambridge, Harvard University Press).

Warren, Austin. (1957) “Emily Dickinson," Sewanee Review. IXV (Autumn, 1957).

Whicher, George Frisbie. (1957). This Was a Poet: A Critical Biography of Emily Dickinson. Ann Arbor: University of Michigan Press.

Wilbur, Richard. (1996). "Sumptuous Destitution”. ed. Judith Farr. Emily Dickinson: A Collection of Critical Essays (Prentice-Hall).

Winter, Yvor. (1947). "Emily Dickinson and the Limits of Judgment". Defense of Reason. $3^{\text {rd }}$ ed. (Denver: The Swallow Press). 